\title{
An Investigation into the Relationship between Family Religiosity and Amount of Violations against Women among Yasuj Educated Families in Year 2015
}

\author{
Zainab Zahedirad1, Asghar Mohamadi² \\ ${ }^{1}$ Department of Sociology, Broujerd Branch, Islamic Azad University, Borujerd, Iran \\ ${ }^{2}$ Department of Sociology, Dehaghan Branch, Islamic Azad University, Isfahan, Iran \\ Email:khabat.khosravi@gmail.com
}

How to cite this paper: Zahedirad, Z. and Mohamadi, A. (2017) An Investigation into the Relationship between Family Religiosity and Amount of Violations against Women among Yasuj Educated Families in Year 2015 Open Journal of Social Sciences, 5, 162-174.

https://doi.org/10.4236/jss.2017.52016

Received: January 6, 2017

Accepted: February 21, 2017

Published: February 24, 2017

Copyright $\odot 2017$ by authors and Scientific Research Publishing Inc. This work is licensed under the Creative Commons Attribution International License (CC BY 4.0).

http://creativecommons.org/licenses/by/4.0/

cC)

\begin{abstract}
Violence against women in families is an annoying fact. The aim of this research is to investigate the relationship between family religiosity and the amount of violation against women among Yasuj educated families in year 2015. Research method in the ready essay is a kind of descriptive and non-experimental and is that of interrelation. Statistical population is all educated families who have passed at last 3 years of their married life in Yasuj. 335 educated women in Yasuj are selected as samples that have been certified by Morgan chart. Data were collected by using two questionnaires of home violation against women by Tabrizi and co-workers (2012) and visitational questionnaire by Glock and Stark. Finding results show inverse correlation between family religiosity and the violence reported inverse correlation between family religiosity and the violation reported by women. There was a positive and meaningful correlation among men education level, number of children, length of marriage, patriarch believes and violation against women in understudying sample.
\end{abstract}

\section{Keywords}

Violation against Women Family Religiosity Patriarch Believes

\section{Introduction}

Violation against women is one of basic problems about public health and human and human rights in modern world. This world phenomenon affects millions of women all over the world in all cultures and social classes. 
In Iran because of cultural and religious characteristics violating against women in street, working environment of the society is much worse than western societies. The most prevalent kind of violation against women is that of hidden ones because a great number of women prevent its mentioning because of such reasons as shame pudency and honor preservation. What makes necessity of paying attention to this subject more serious is that violation against women in addition to harmful effects on personal life causes negative results such as feeling unsafe, disorder in social relationships and direct effect on children breeding and its existence for women of society lessening the possibility of proper use of their ability and talent [1]. So, removal of legal and lawful straits, planning precautionary, educational and supportive plans, predisposition for women abilities and needed social and legal supports are the most important policies that should be considered in macro plans and policies codification. As far as the importance of family as the unit for recognition and understanding of marriage and divorce patterns on one hand and necessity of considering harms, subjects and problems of women society and importance of considering such problems in more traditional societies on other hand, and also the necessity of considering religious principles in families, writer in the ready research is going to consider the relationship between family religiosity and the amount of violation against women among educated families in Yasuj [2].

\section{Foreign Background of Research}

Leary studies [3] Murray A Straus and Unit and Murray [4], Neill (1993) as quoted by Michaeal [5], Muarray [4] are of the other researches done on home violation. In sequel we will consider the researches done during this late years.

Margolin [4], in a research under the subject "violation against women", a successful human rights outlook from potentials and challenges point of view declares that "violation against women" considered as violation of human right by statemen has not been Considered important during the late decades. Till Health and human rights movement for women started its activities and fought strongly against sex-related violations against women and now some famous civil and law institutions have been found in all over the world. Murray [6] has considered a research under the subject "an investigation on the amount of violation against women by family in Colombia". in this research information have been collected on both men and women during 15 months and concluded that women who have grown up in families in which there had been violation they have not reacted much to their husband violation and don't know some kinds of violation as violation. Men, who had grown up in families in which there had been violation, had practiced it in their lives more than others [7].

Michael [5] in a public opinion polling in a research under the subject of "Reasons for obliteration of intimacy and causing violation between wife and husband vote the argument says" as intimacy obliterates in families and wife and husband try to struggle with each other for proving themselves, violation on behalf of wife and husband toward each other increases. 
Thorton \& Exine [8] have investigated on the relation between violation against women and divorce rate and have concluded that violation plays an important role in aggravating ascending trend of divorce rate. Especially about those who have experienced an unsuccessful married life once before. They assume divorce as a choice to get rid of violation.

\section{Internal Empirical Background}

Schafer [9] in a research under the subject the "effect of education intervention on increase of self-effectiveness and Women Knowledge for Preventing house violation" concluded that in order to reduce house violation against women it would be offered to increase their knowledge and self effectiveness by holding right educational and planning courses.

Shepard [10] in a research under the subject "an analysis of dimensions of violation against women and religiosity in family in Yasuj" has searched in a measuring research among married women at ages $15-54$ who have passed at least one year of their married life and the finding has revealed that among religiosity dimensions there just wasn't a meaningful correlation between emotional dimension with phenomenon of violation against women, but there was generally a meaningful one among other dimensions and variable. The highest level of correlation was among ritual dimension with dimensions of violation against women. He concluded that by increasing the religiosity of men especially in ritual and faith dimensions, violation against women especially in economical and sexual dimensions, violation against women will decrease [8]. This finding shows that using religious doctrines in society, especially in family can play an important role in decrement of violation. Religious doctrines don't irradiate violation, so, considering religious doctrines for decreasing violation is a suggested technique.

Schumacher et al. [11] in a research under the subject "violation against women on Quranic point of view" considers socialists views about family and family violation and social misconduct And consideration of this idioms by using etymology and creating Quranic concepts network and related commentary verses and anecdotes this research has talked about Quran strong disagreement with violation against women by using content analysis method and in an attributive theoretical framework direction.

Smith [12] has done a research under subject of family violation and its effects on safety of society. Understudying sample is a sample in Sananadaj. And its main purpose is family violation and its effects on social safety of Sanandaj. Its research method is measurement and data is collected by questionnaires. Its finding show that 3 variants of family violation, religious believes and patriarch believes have effects on determination of variance of dependent variant in order and this 3 could have taken into account $42 \%$ of dependent variant variance.

Soler et al. [13] have done a research under the subject "an investigation on women reacts against their wives violation". They have done this research by considering the correlation between women age, number of children and educa- 
tion level. Its statistical sample is 125 women who referred to Isfahan Welfare offices and they have been selected at random.

\subsection{Theoretical Principles of the Research}

Among different kinds of violation even family, social and state, family violations especially those against women are a serious social harm that shows itself off despite cultural and intellectual developments. This kind isn't special to urban or rural life. Wife disturbing goes far beyond classical and racial boundaries. Home violation is the kind that is practiced in a personal environment. The fact that women are damaged by men violation was hidden till $70 \mathrm{~s}$ [14]. Violation is practiced in different cultural levels and doesn't belong to any certain class. Though violation against women is prevalent in all societies but the more societies are poorer, more traditional and less eructated, the more will be expenses and intensity of violation against women and its consequences. It's about $3 \mathrm{dec}-$ ades that researchers are considering home violation against women seriously [6].

Subjects related to wife violation are being followed in research projects and dissertations forms and even in national forms and have been digressed to a large extent from narrative journalistic form. Even though home violation in families is a hidden matter and complaint cases about wife disturbing is much less than real and in most items women hide home violation in order to preserve family unity and dignity [14].

\subsection{Amount and Prevalence of Violation against Women}

Violation against women is counted as an important factor for bringing them physical and mental damages. That is in different forms such as home violence, sex abuses, women and girls business, obligatory infamy, violations resulted from war like murder, sexual abuses and obligatory pregnancy. Women battery by their husbands is the most prevalent kind and includes about $20 \%$ women sexual abuse and home violations causes women health to be removed at ages 15 24 more than illnesses such as breast and womb cancer, painful childbirths war and accident [15].

In a research by Smith [12] in two third wife disturbing cases, other than using fist and kicking as the most common way of physical violation, they also have used battery weapons against women. Also $95 \%$ of enquirers have had the experience of being battered by their husbands more than 3 times. $81.6 \%$ women under study were battered with fist and $68.7 \%$ have been battered by battery weapons such as belt, stick, knife and spit In addition to fist and kicking. And wife disturbing happens in Iran at $83.5 \%$ rate during the first year of married life that is similar to other studies such as that of Nazparvar (81\%).

\section{Research Method}

The ready research, regarding subject nature and noted goals is known as that of descriptive (non experimental) and is kind of correlative. In this kind of re- 
search, the relation between variables will be analyzed, meaning the relationship between family religiosity and violence against women will be analyzed. And since date is collected and analyzed based on family view, this research is kind of measuring. So it can be said that the ready research method is a mixture of two measuring and correlative research methods.

Methods used for collecting information for this research are two questionnaires of violation against women and Glock and Stark visual questionnaires. Statistical sample of this research is all education families of Yasuj. Among theses, those women are included who have passed at least 3 years of their married life. According to gotten results the number of people employed in Yasuj Education is 3000 and 2600 persons are married ones who are the statistical sample of this research.

Selected sample for this research is education families in Yasuj and in order to choose representative sample margin chart has been used. Regarding the amount of statistical sample that is 2600 parsons, representative sample is 335 persons.

\section{Sampling Method}

Sampling is one of the most important subject in social statistics, because on one hand regarding the expanse of population or under studying Subjects, researcher is forced to do sampling and it's inevitable except in exceptional cases (like Cencus), and on the other hand the validity of a research findings is measured by sampling accuracy. Sampling is done in two Rorms of probable and improbable. probable is better than improbable because very probably it causes representative sample and makes it possible to estimate sample accuracy. Probable sample is divided into four main types: simple random sampling, systematic sampling, stratified sampling and multistage cluster sampling. Choosing each probable type depends upon research subject nature, existing a suitable sampling framework, expense, desired accuracy level in sample and method for collecting data. In order to choose sample in this research multistage cluster sampling method is used. It has been describe at the bellow:

1) First, female schools of Rasouj were geographically divided into four regions of North (15 schools), East (24) schools, south (18 schools) and west (22) schools

2) 5 schools were selected at random in each region.

3) A list of married women in these schools was prepared and the sample was selected at random and the questionnaire was distributed.

\section{Analysis Unit}

Analysis unit is a unit data are collected based on it. The unit its characteristics are explained in this research the mentioned unit is "person". In other words we ask people about data.

Concepts defined in this research theoretically and operationally are the research variables. Variables are some of the most important concepts in socialhuman researches. The aim is to identify the Cause or Causes for occurrence or 
change in the under studying subject and since these factors are changeable and measurable we name them variable.

Dependent variable: Variable that is affected by an on other variable or variables (128). This variable for ready research is "drivers tendency to narcotics".

Independent variable: variable that affects other variables. Independent variables in this research are proportional deprivation feeling, friends group, Social Control, self-estrangement feeling.

\section{Discussion and Analysis}

Based on the results of Table 1, the highest reported violation in that of social with $43.58 \%$ severity degree, and the lowest is that of sexual with $7.16 \%$.

\subsection{Findings Related to Research Hypotheses}

\subsubsection{First Hypothesis Test}

There is correlation between religious families and violation against women.

In order to investigate the correlation between the level of family religiosity and dimensions of home violation Pearson coefficient of Tables 2-7.

According to aforesaid table information there is a reverse and meaningful correlation between general index of religiosity and different dimensions and subdimensions of violation against women. In all cases, coefficient of correlation is negative and is calculated at level $\mathrm{p}<0.001$, the highest calculated coefficient in between physical violation and general index of religiosity with -0.395 and the lowest is between mental-verbal violation and belief component that is equal to -0.008 , the reverse coefficient of general index of violation against women -0.356 at level $\mathrm{p}<0.001$ (Table 8 ).

\subsubsection{Second Hypothesis Test}

There's correlation between Couples age difference and violation against women. Spear man coefficient correlation has been wed to answer this hypothesis and the results have come in Table 9.

Regarding the results of Spearman Coefficient of correlation on 335 persons, coefficient of correlation for couples age difference and violation against women at level $\mathrm{p}<0.001$ equals to 0.25 that represents a positive and meaningful correlation.

\subsubsection{Third Hypothesis Test}

There's a meaningful difference between men and women education level and

Table 1. Descriptive statistics of kinds of men violation against educated women.

\begin{tabular}{ccccccccccc}
\hline \multicolumn{2}{c}{ Never } & \multicolumn{2}{c}{ Hardly ever } & \multicolumn{2}{c}{ Sometimes } & \multicolumn{2}{c}{ Often } & \multicolumn{2}{c}{ Always } & Violation type \\
\cline { 1 - 7 } percent & frequency & percent & frequency & percent & frequency & percent & frequency & percent & frequency & \\
\hline 2.38 & 8 & 10.44 & 35 & 18.50 & 62 & 39.40 & 132 & 29.25 & 98 & Mented-verbal violation \\
2.38 & 8 & 3.28 & 11 & 23.58 & 79 & 43.58 & 146 & 27.16 & 91 & Social violation \\
13.73 & 46 & 43.88 & 147 & 10.14 & 34 & 18.50 & 62 & 13.73 & 46 & Physical violation \\
17.31 & 58 & 59.40 & 199 & 8.65 & 29 & 7.64 & 25 & 7.16 & 24 & Sexual violation \\
\hline
\end{tabular}


Table 2. Correlation between couples age difference and violation against women.

\begin{tabular}{|c|c|c|c|c|c|c|c|}
\hline Partial $\eta^{2}$ & Meaning level & F & Average of square roots & df & $\begin{array}{l}\text { Total of squome } \\
\text { roots }\end{array}$ & \multicolumn{2}{|c|}{ Statistics Sources } \\
\hline 0.989 & 0.001 & $30,299.248$ & $692,679.359$ & 1 & $692,679.359$ & Women education level & \\
\hline 0.986 & 0.001 & $23,245.006$ & $867,992.680$ & 1 & $867,992.680$ & Men education level & \\
\hline 0.055 & 0.001 & 9.908 & 226.505 & 2 & 453.010 & Women education level & Violation \\
\hline \multirow[t]{5}{*}{0.032} & 0.004 & 5.617 & 209.746 & 2 & 419.492 & Men education level & women \\
\hline & & & 22.861 & 333 & 7818.555 & Women education level & \multirow{2}{*}{ Error } \\
\hline & & & \multirow[t]{3}{*}{37.341} & 333 & 1270.635 & Men education level & \\
\hline & & & & 335 & $842,507.00$ & Women education level & \multirow{2}{*}{ Total } \\
\hline & & & & 335 & $1,061,330.00$ & Men education level & \\
\hline
\end{tabular}

Table 3. Meaningful difference between men and women education level and violation against women.

\begin{tabular}{ccccc}
\hline $\begin{array}{c}\text { Meaningfulness } \\
\text { level }\end{array}$ & Standard error & $\begin{array}{c}\text { Difference between } \\
\text { averages }\end{array}$ & J group & I group \\
\hline 0.001 & 0.62 & 2.23 & Junier diploma & Diploma \\
0.001 & 0.78 & 3.25 & B. A and higher & Junior college \\
0.13 & 0.67 & 1.01 & B. A and higher & \\
\hline
\end{tabular}

Table 4. Comparison of the groups SHOFEH test.

\begin{tabular}{ccccc}
\hline $\begin{array}{c}\text { Meaningfulness } \\
\text { level }\end{array}$ & Standard error & $\begin{array}{c}\text { Difference } \\
\text { between averages }\end{array}$ & J group & I group \\
\hline 0.02 & 0.79 & 1.93 & Junior diploma & Diploma \\
0.001 & 0.99 & 3.24 & B. A and higher & Junior college \\
0.13 & 0.86 & 1.31 & B. A and higher & \\
\hline
\end{tabular}

Table 5. Comparison of the groups SHOFEH test.

\begin{tabular}{|c|c|c|c|c|c|c|}
\hline \multicolumn{2}{|c|}{ Severe $(81-120)$} & \multicolumn{2}{|c|}{ Middle (41 - 80) } & \multicolumn{2}{|c|}{ Low $(0-40)$} & \multirow{2}{*}{$\begin{array}{l}\text { Violence number } \\
\text { Number of children }\end{array}$} \\
\hline Percent & Frequency & Percent & Frequency & Percent & Frequency & \\
\hline 0 & 0 & 42.10 & 8 & 57.90 & 11 & With no child \\
\hline 13.79 & 12 & 36.78 & 32 & 49.42 & 43 & One child \\
\hline 40.13 & 52 & 63.26 & 93 & 27.89 & 41 & Two children \\
\hline 54.90 & 28 & 19.60 & 10 & 25.49 & 13 & Tree children \\
\hline 51.61 & 16 & 35.48 & 11 & 12.90 & 4 & For children more \\
\hline
\end{tabular}

Table 6. Total marks of violation against women are based on Marriage period length.

\begin{tabular}{ccccccc}
\hline \multicolumn{2}{c}{ Severe $(\mathbf{8 1}-\mathbf{1 2 0})$} & \multicolumn{2}{c}{ Middle $(\mathbf{4 1}-\mathbf{8 0})$} & \multicolumn{2}{c}{ Low $(\mathbf{0}-\mathbf{4 0 )}$} & Violence number \\
\hline Percent & Frequency & Percent & Frequency & Percent & Frequency & Marriage period length \\
\hline 9.75 & 4 & 24.39 & 10 & 65.85 & 27 & Less than 5 \\
26.92 & 21 & 48.71 & 38 & 24.35 & 19 & 5 to 10 \\
47.87 & 45 & 32.97 & 31 & 19.14 & 18 & 11 to 15 \\
27.86 & 34 & 55.73 & 68 & 16.39 & 20 & 16 to 20 \\
\hline
\end{tabular}


Table 7. The amount of coefficient of correlation between patriarch believes and violation against women.

\begin{tabular}{ccc}
\hline Violation against women & Statistical index & Variable \\
\hline 0.823 & Pearson coefficient of correlation & \\
0.00 & Meaningfulness level & Patriarch believes \\
335 & Number & \\
\hline
\end{tabular}

Table 8. Pearson coefficient of correlation between religiosity different dimensions and dimensions of violation against women.

\begin{tabular}{|c|c|c|c|c|c|c|}
\hline $\begin{array}{l}\text { General index of } \\
\text { religiosity }\end{array}$ & Ceremonial & Consequential & Emotional & Belief & \multicolumn{2}{|c|}{ Violation dimensions } \\
\hline-0.198 & -0.021 & -0.041 & -0.072 & -0.008 & Index & \multirow{2}{*}{$\begin{array}{l}\text { Mental-verbal } \\
\text { violation }\end{array}$} \\
\hline 0.001 & 0.001 & 0.001 & 0.001 & 0.001 & Meaning level & \\
\hline-0.26 & -0.18 & -0.75 & -0.23 & -0.19 & Index & \multirow{2}{*}{ Social violation } \\
\hline 0.001 & 0.001 & 0.001 & 0.001 & 0.001 & Meaning level & \\
\hline-0.395 & -0.21 & -0.39 & -0.08 & -0.32 & Index & \multirow{2}{*}{ Physical violation } \\
\hline 0.001 & 0.001 & 0.001 & 0.001 & 0.001 & Meaning level & \\
\hline-0.371 & -0.358 & -0.210 & -0.154 & -0.128 & Index & \multirow{2}{*}{ Sexual violation } \\
\hline 0.001 & 0.001 & 0.001 & 0.001 & 0.001 & Meaning level & \\
\hline-0.356 & -0.357 & -0.210 & -0.154 & -0.074 & Index & \multirow{2}{*}{$\begin{array}{c}\text { General index of } \\
\text { violation against } \\
\text { women }\end{array}$} \\
\hline 0.001 & 0.001 & 0.001 & 0.001 & 0.001 & Meaning level & \\
\hline
\end{tabular}

Table 9. Correlation between couples difference and violation against women.

\begin{tabular}{cccc}
\hline Meaning level & Correlation & Sample number & Variable \\
\hline 0.001 & 0.25 & 335 & \\
\hline
\end{tabular}

violation against women.

In order to answer this hypothesis, multivariable variance analysis (Manova) has been used. Regarding the amount of M. Box test dependent variable proves the hypothesis for equity of co-variance matrixes. Also Lon test results showed that hypothesis for equity of variance error in men education level variable ( $\mathrm{f}=$ 0.88 , sig $=0.42$ ) is proved. The results of multivariable variance analysis are showed in Table 5.

Results of the aforesaid table show a separable comparison between men and women education level. The results show that there's a meaningful correlation between women education level at level $\mathrm{p}<0.001$. There's a meaningful correlation between men education level at level $\mathrm{p}>0.004$. In order to compare the groups SHOFEH test has been used that its results have been showed in Table 6.

Result of Shofeh provocative test show that there is a meaningful those with junior college certificate and B-A and higher education levels and violation against women at the level $\mathrm{p}<0.001$ but this meaningful difference doesn't exist between senior college and B-A and higher levels recording violation women with low education levels and diploma have reported most violation.

Shofeh test result show that there's a meaningful difference between men with 
a diploma and those with B-A education levels and higher once in level $\mathrm{p}<$ 0.001, but this difference doesn't exist between junior College level and B-A and higher levels. Men with diploma education level have practiced most violation against women.

$$
P<0.001, d f=20, \chi^{2}=9.81
$$

\subsubsection{Fourth Hypothesis Test}

Violation amount against women differs based on number of children. In order to answer this hypothesis khi2 test has been used that its result can be seen in fallowing.

$$
P<0.001, d f=20, \chi^{2}=17.2
$$

Result shows that kh2 amount $(x=1712)$ in level $(\mathrm{p}=0.001)$ between variables marriage correlation. And the most violation amount has been reported in families with 3 children with equals $54.90 \%$ and the least amount has been reported for families with no children which equals zero.

\subsubsection{Fifth Hypothesis Test}

There's correlation between marriage length and violation against women. In order to answer this hypothesis khi2 test has been used and its results can be seen in Table 9.

Result show that khi2 amount $(x=1712)$ in level $(p=0.001)$ reports a meaningful correlation between marriage percent of violation is reported in families who have passed 11 - 15 years of their married like which equals $47.87 \%$ and the least one is for families who have passed less than 5 years of their married life which equals $9.57 \%$.

\subsubsection{Sixth Hypothesis Test}

There's correlation between patriarch believes and violation against women. In order to test this hypothesis for determining variability of two variables and also because of difference level used in patriarch view variable (independent variable), Pearson Coefficient of Correlation Test has been used and it can be seen in Table 10.

Regarding the result of aforesaid table between patriarch variable and violation against women, coefficient correlation 0.823 at meaningful level 0.00 expresses a meaningful completion between patriarch believes and violation against women with the possibility of 0.99 .

\subsubsection{Seventh Hypothesis Test}

Violation against women in under studying society is transmitted regarding to traditions and family breeding. In order to response this hypothesis the multiple regression analysis has been used simultaneously and its results have been showed in Table 11 and Table 12.

The results of the aforesaid tables show that the model of the effects of traditions and family breeding on violation against women ( $\mathrm{f}(342,2=9.81, \mathrm{p}<$ 0.001 ) was meaningful this model justifies 4.9 violation against women variance. 
Table 10. Summary of the model of the effect of traditions and family breeding on violation against women.

\begin{tabular}{ccccc}
\hline Standard error & $R^{2}$ arranged & $R^{2}$ & $R$ & $\begin{array}{c}\text { Statistics } \\
\text { Model }\end{array}$ \\
\hline 3.17 & 0.049 & 0.054 & 0.233 & Effective factors on violation \\
\hline
\end{tabular}

Table 11. Variance mode analysis the effect of traditions and family breeding on violation against women.

\begin{tabular}{cccccc}
\hline $\begin{array}{c}\text { Meaningfulness } \\
\text { level }\end{array}$ & F & $\begin{array}{c}\text { Squares } \\
\text { mean }\end{array}$ & $\begin{array}{c}\text { Freeness } \\
\text { degree }\end{array}$ & Total of squares & Statistics \\
\hline \multirow{2}{*}{0.001} & 98.434 & 2 & 196.869 & regression \\
& 9.811 & 10.03 & 333 & 3431.363 & remainder \\
& & & 335 & 3628.232 & Total \\
\hline
\end{tabular}

Table 12. Indexes of the model of the effect of traditions and family breeding on violation against women.

\begin{tabular}{cccccc}
\hline \multirow{2}{*}{$\begin{array}{c}\text { Meaningfulness } \\
\text { level }\end{array}$} & $\mathbf{t}$ & \multicolumn{2}{c}{$\begin{array}{c}\text { Standard } \\
\text { coefficient }\end{array}$} & & Statistics \\
\cline { 3 - 5 } & & $\boldsymbol{B}$ & $\begin{array}{c}\text { Error } \\
\text { Standard }\end{array}$ & $\mathbf{B}$ & Variable \\
\hline 0.001 & 18.962 & & 1.905 & 36.126 & Fiyedarmount \\
0.022 & 2.297 & 0.135 & 0.039 & 0.089 & Traditions \\
0.020 & 2.339 & 0.138 & 0.031 & 0.072 & Family breeding \\
\hline
\end{tabular}

(B) coefficients show that traditions and family breeding was a meaningful predictor for violation against women. Beta coefficients show that family breeding has more effect on violation.

\section{Conclusions}

The goal of ready research was to investigate correlation between family religiosity and an amount of violation against women among educated families in Yasouj. A group of 335 educated women who were chosen at random were asked to fill in questionnaires. Investigation was done with seven hypotheses and in this chapter we will discuss about results. In order to do this, we are to explicate the hypotheses. What clarifies the importance of this research knows not only man but also women responsible for violent actions of husband and the reason for violation is not in their characteristics but in those of their husband. Most of these men are in a low rank regarding education, payment and job situation and have a little self-confidence. Accepting such behavior is social more than being individual and violation against the women is not limited by physical violation but every kind of behavior that man practices on women in order to prove his power to control her. It also includes those kinds of mental social, economic and sexual.

Educated families by recognizing ways to go along with conflicts in close relation have reduced violation in families and ask a ritual way for help. 
Esfand Abad research findings declare that wife disturbing has a reverse meaningful correlation with couples' education level in such a way that highly educated women are less disturbed compared with those with low education.

\section{Hypothesis Explication}

First hypothesis: there's correlation between religious families and violation against women.

According to the results of coefficient of correlation there is on inverse negative correlation between family religiosity and violation against women, as a proof families who had reported a high level of religiosity have gotten a low mark in violation against to women. Second hypothesis: there's correlation between couples age difference and violation against under Studying women.

Regarding the results of correlation coefficient there was a positive and meaningful correlation between couples age difference and violation against women. The more the difference the more the violation against women was seen.

In such families the older person knows him/her self responsible for dictating the other one because of his/her experience, and much dictating which is not always right but taste interferes too much, too, and causes violation against partner. He think he/she should breed the younger one, but the younger one expects to live, not his/her partner play his/her father or mother role and try to breed him/her. Mutual understanding and difference in way of thinking because itself a cause of violation. Third hypothesis: there's a meaningful difference between men and women education level.

Based on the results of multi-variable variance and Shofeh test in has become specified that there's a positive and meaningful correlation between education level and extensity of violation against women. The less education level, the more women are violation and the less education level for men, the more they have practiced violation. One of family harmful characteristics is much number of children which is usually accompanied by a little age difference between them. In big families there is no chance for looking after the children financially, emotionally and educationally. Despite his hardworking, father can't afford well for life expenses and mother though working continuously, it's hard for her to settle the affairs at home especially if she works out too. And as a result both tired of the hard work they themselves have created for themselves and their children are impatient for both just and unjust requests from their children. Stress, anxiety and nervousness are features of such families. Fifth hypothesis: there's a correlation between marring length and violation against under studying women.

Regarding khi2 test results there's a positive and meaningful correlation between violation against women and marriage length. There is more violation in families who have passed more time since their marriage. In families who there's no discourse, mutual discussion and democratic exchange of ideas or there's no authority, unjust power relation will be a factor for practicing violation from authorized persons to weak ones, paying more attention to boys rather than girls, considering manliness more important and living of many families in the 
Same house have even provided for violation of women against women.

By getting older, being tough, powerful, more merciless, independent, and having ability to risk usually become characteristics of Man and being subservient, quiet, Shy and dependent are become the accepted characteristics of women or they are expected to do so at least. In addition having little knowledge or no knowledge about rules causes the person who violates to repeat his/her behavior in future and not to fear the consequences of his behaviors. Sixth hypothesis: there's Correlation between patriarch believes and violation against women.

Based on the results of Pearson Coefficient of Correlation there is positive and meaningful correlation between patriarch believes and violation against women.

Patriarch can be regarded as an ordered organization of men superiority and women underneath. In fact, it emphasizes on description and explication of reasons of men and women inequity in society. Continue in violation in society by men continues their superiority on women in society, in fact. Family holiness and preserving its information in its environment declares its intimacy in public a private environment which is the basis for the theory of secretiveness. That is one of reasons for violation against women. Another cultural reason is acceptance and legitimacy of practicing violation against women is families many Countries. For decades hitting women and children has been regarded as some necessities of patriarch family system. There are cultural permits for women punishment and battery that can be found in past cultural heritage. Seventh hypothesis: violation against women in under studying society is transmitted according to traditions and family breeding.

In order to analyze this hypothesis regression was used and results clarified that traditions and family breeding affects violation against women. The effect of family breeding was more than traditions.

According to cultural theory culture is a set of merits and relations that transmits from one generation to another and affects human present and future behavior. Salehi \& Salehi research findings (2004) know cultural factors as effective factors in practicing violation (with 12.6\%). Sometimes it has been observed that local and ethnical traditions act more strongly than law against women (Pooladi \& Shalviri, 2000). This researcher says another reason for continuing violation against women is its tolerance from women themselves that this subject is same with experienced distress situations and woman concludes that her efforts for changing man is useless. So; conciliates with this situation. And this has always been observed among aged women. But young women mostly defend and persist against their husbands.

The theory of theorists like Abot and Wallas who believe in relation and effect of formal rules and believes and breeding in amount of family violation is true here. Wrong education, distrust in person and society level, physical and mental discontinuity in family normal relations and finally violation flow are the common results of harsh behavior. Since the ready generation is expected to educate and grow their next healthy and skilled generation, importance of confronting 
violation and its related problems becomes gradually clear.

\section{References}

[1] Afrasyabi, A. and Sajjad, L. (2013) The Police Response to Violence against Women in Social Environments (a Comparative Study of the Criminal Policy of Iran and Canada). Police Journal, Issue 21.

[2] Ahmad, H. (2003) Sociological Analysis of the Factors Affecting Husbands' Violence against Women in the Family Case Study in Bushehr. The First Conference of Social Pathologies in Iran, Khordad, 1381.

[3] Leary, K.D. (1993) Through Psychological Lense: Personality Trait, Personality Disorders, and Level of Violence. In: Gelles, R.J. and Loseke, D.R., Eds., Current Controversies on Family Violence, Sage, Newbury Park, CA, 7-39.

[4] Straus, M.A. (2014) Addressing Violence by Female Partners Is Vital to Prevent or Stop Violence against Women: Evidence from the Multisite Atterer Intervention Evaluation. Violence against Women, 20, 889-899. http://dx.doi.org/10.1177/1077801214545932

[5] Michael, P. (2014) Intimate Terrorism and Situational Couple Violence in General Surveys: Ex-Spouses Required. Violence against Women, 20, 186-207.

[6] Margolin, G., John, R.S. and Foo, L. (1998) Interactive and Unique Risk Factor for Husbands Emotional and Phsycal Abuse of their Wives. Journal of Family Violence, 13, 315-344. http://dx.doi.org/10.1023/A:1022880518367

[7] Anderson, S. (2010) Sex, Familial Status and Violence. Social Forces, 85, 354-387.

[8] Thornton, D. and Exine, A. (2012) Investigate the Relationship between Violence against Women and Divorce Rates. Women's Views, Violence against Women, 10, 641.

[9] Schafer, J. (1996) Measuring Spousal Violence with the Conflict Tactics Scale. Journal of Interpersonal Violence, 11, 572-586. http://dx.doi.org/10.1177/088626096011004008

[10] Shepard. M.F. and Campbell, J.A. (1992) The Abusive Behavior Inventory: A Measure of Psychological and Physical Abuse. Journal of Interpersonal Violence, 7, 291 305. http://dx.doi.org/10.1177/088626092007003001

[11] Schumacher, J.A., Feldbau-Kohn, F., Slep, A.M.S. and Heyman, R.E. (2001) Risk Factors for Male-to-Female Partner Physical Abuse. Aggression and Violent Behavior, 6, 281-352. http://dx.doi.org/10.1016/S1359-1789(00)00027-6

[12] Smith, M.D. (1990) Patriarchal Ideology and Wife Beating: A Test of a Feminist Hypothesis. Violence and Victims, 5, 257-273.

[13] Soler, H., Vinayak, P. and Quadagno, D. (2000) Biosocial Aspects of Domestic Violence. Psychoneuroendocrinology, 25, 721-739. http://dx.doi.org/10.1016/S0306-4530(00)00022-6

[14] Spence, J.T. and Helmreich, K.L. (1972) The Attitude toward Women Scale: An Objective Instrument Measure Attitude toward the Right and Role of Women in Contemporary Society. JSAS Catalogue of Selected Document in Psychology, 2, 66-67.

[15] Spss Base 9.0: Applications Guide. Copyright (1999) by Spss Inc., Printed in United States of America. 16-660. 